\title{
THE VALUES OF PANCASILA IN BUSINESS ACTIVITIES IN INDONESIA (CASE STUDIES OF LIMITED LIABILITY COMPANY AND COOPERATION)"
}

\author{
Sulistiowati $^{* *}$, Nurhasan Ismail ${ }^{* * *}$, Paripurna $^{* * * * *}$, and Sulastriyono ${ }^{* * * * *}$ \\ Business Law Department, Agrarian Law Department, Adat Law Department, Faculty of Law \\ Universitas Gadjah Mada, Yogyakarta \\ Jalan Sosio Yustisia No. 1, Bulaksumur, Sleman, D.I. Yogyakarta, 55281
}

\begin{abstract}
This research was conducted to identify the values of Pancasila in business activities with case studies of cooperation and limited liability company in Indonesia. This research is a socio-legal studies that discuss the relationship values of Pancasila as the nation's philosophy of life and economic law as the legal basis for the development of business activities in Indonesia. The results showed values of Pancasila very relevant to be applied in business activities, most of which have been accommodated in the laws and regulations governing business activities in Indonesia, but there are also some content of value that has not been accommodated.
\end{abstract}

Keywords: Pancasila, limited liability company, cooperation.

\section{Intisari}

Penelitian ini dilakukan untuk mengidentifikasi tata nilai Pancasila dalam kegiatan usaha dengan studi kasus koperasi \& perseroan terbatas di Indonesia. Penelitian ini merupakan kajian sosio-legal yang membahas keterkaitan nilai-nilai Pancasila sebagai falsafah hidup bangsa dan hukum ekonomi sebagai landasan bagi pembangunan hukum kegiatan usaha di Indonesia. Hasil penelitian menunjukkan nilai-nilai Pancasila sangat relevan untuk diterapkan dalam kegiatan usaha, yang sebagian besarnya telah diakomodir dalam peraturan perundang-undangan yang mengatur kegiatan usaha di Indonesia, namun terdapat pula beberapa kandungan nilai yang belum terakomodir.

Kata Kunci: Pancasila, perseroan terbatas, koperasi.

\section{Pokok Muatan}

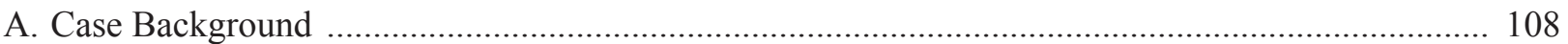

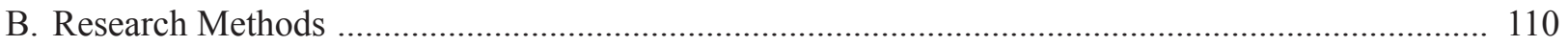

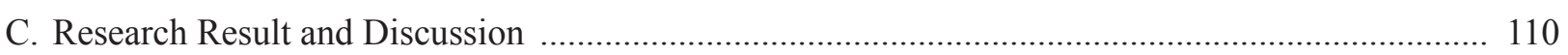

1. The Values of Pancasila that can be Applied in Business Activities .......................................... 111

2. Determination of Parameter of Each Principle of Law ........................................................... 118

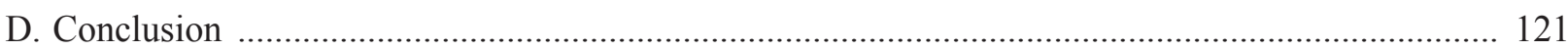

* This research is funded by Dikti, Batch I, 2015

** Correspondence address: sulistyowati.fhugm@gmail.com

*** Correspondence address: nurhasan.ismail@gmail.com

**** Correspondence address: paripurna@gmail.com

${ }^{* * * * * * *}$ Correspondence address: sulastriyono@yahoo.com 


\section{A. Case Background}

Current reality shows that business and trade activities in Indonesia are changing very fast, dynamic, and complex. Science, technology of information, and the development of payment systems, changes in people's behavior, increased the activity of cross-border trade and trade cooperation between countries have been foster the change and expanding the range of ruling.

Facing this global constellation, almost no country is shut out of the global economic association. Adoption of modern values is seen as a necessity of the ongoing global phenomenon. It is also happening within the laws of economics. Globalization and the establishment of a multilateral economic cooperation became the main supporting factors of the adoption of foreign values on economic law in Indonesia. In fact, before the era of globalization and the emergence of various multilateral economic cooperation, Indonesia has adopted legislation of economic from Indies.

In fact, some areas of new laws related to business and trade activities have emerged and developed, such as business competition law or intellectual property rights. In fact, those areas of law have established a separate legal discipline, following the legislation of its own, incorporating within aspects of administrative law, and when deemed necessary, also equipped with aspects of criminal law. ${ }^{1}$

Transplantation of foreign law without adjustment within the local values become a modernity trap. ${ }^{2}$ Pancasila as the philosophy of the nation, which vibrant and support every facet of life, including business activities in Indonesia. However, the reality of the business activities in Indonesia indicate otherwise. The values of Pancasila are missing from the joints of national life in Indonesia.
The drafting of various academic texts of legislations related to business activities has actually been used Pancasila as the basic philosophy, but the existence of Pancasila seems just a patch. Within the scope of the arrangements, there have not been showed the values of Pancasila. So is the case, the basic of sociological is also not incorporating within the local values as an integral part of business activities in Indonesia.

The practice of the law of Limited Liability Company showed a similar thing. The applicability of the legal principles of the limited liability company as an independent legal entity regardless of its shareholders and the principle of limited liability law that imposes limited liability for the value of its shares. This protection can certainly encourage the emergence of opportunistic attitude of shareholders to utilize the limited liability company for the private interests of shareholders. $^{3}$

These businesses opportunistic attitude shown by the existence of a group of companies or so-called conglomerate into a form of business that has been chosen by businessmen in Indonesia. The rapid growth of the number of the group companies in Indonesia are influenced by a variety of motives, such as the creation of added value through the synergy of several companies, the efforts to achieve a competitive advantage which exceeds any other company. ${ }^{4}$ The formation or the company's growth cannot be separated from the reality of business ongoing. Business management through group of companies are considered giving more economic benefit compared to a single company. The change from a single company into a group company is the implications of changing the strategy and structure of a company.

The existence of the group company in business activities in Indonesia is showed by large-

\footnotetext{
Rudhy Prasetya, "Diskusi Publik Mengenai Pembaruan Hukum Dagang”, Paper, Public Discussion on Academic Paper of Commercial Law Bill, BPHN, Jakarta, 31 October 2013.

Ismail, Nurhasan, "Hukum Prismatik: Kebutuhan Masyarakat Majemuk Sebuah Pemikiran Awal”, Speech, Professor Inauguration at Faculty of Law Universitas Gadjah Mada, Yogyakarta, 2011.

Sulistiowati, 2014, Tanggung Jawab Hukum pada Perusahaan Grup di Indonesia, Erlangga, Jakarta.

Sulistiowati, 2010, Aspek Yuridis dan Realitas Bisnis Perusahaan Grup, Erlangga, Jakarta.
} 
scale firms which will no longer be run through the form of a single company, but using construction of Group Company. In fact, the amount of revenue of the top ten group companies in Indonesia reaches 9:27\% of Indonesia's GDP in $2010 .{ }^{5}$

Changes in the values of these businesses not only appears on the forms of business entities that are adopted from outside, but also at the Cooperation. Businessman who put the priority on profit was also appearing on other forms of Cooperation activities. This is shown from various krikik of Bung Hatta in the decade of the seventies of Indonesia's cooperation which seems to be more developed as a cooperation of the board and not cooperation of members. Cooperation organizations such as KUD (Koperasi Unit Desa) formed in all villages in Indonesia with various amenities government handouts without members, and while developing KUD listed the member of farmers to use warehouse the floor to dry the grain, grinding grain machine or funds to buy fertilizers through KUD loans. As a result becoming a member is not a prerequisite the establishment of a cooperation. ${ }^{6}$

In fact, the cooperation is seen solely as a form of business entity, then the exact knowledge to study the cooperation is in a part of microeconomics i.e management. Cooperation's problem is considered solely as a management problem, such as how to manage the cooperation organization to be efficient, and that, as an economic organization, gain maximum benefit such organizations or other companies which are recognized as Limited Liability Company or state-owned enterprises. ${ }^{7}$

Putting the traditional values need to be done to prevent changes in values and further community orientation in running this business. Various traditional values are forms of local knowledge to put the priority in togetherness and avoid greed. The application of the values of local wisdom as a living cultural system, grow, and develop in society. ${ }^{8}$

Based on the reality of Indonesian pluralism, the politic of legal development should be based on the combination of the principles derived from the modern and traditional social value or local wisdom selectively. Prismatic Law is the value system of law which is typical, that distinguishes the Indonesian legal system with other legal systems so that the term of Pancasila which, when linked to the literature on the combination of more than one choice of social values is referred to as an option of prismatic values, therefore in the context of the law can be referred to as prismatic law. ${ }^{9}$

Implementation of Pancasila values in business activities excavated and built from the values espoused in Indonesian society, which can be derived from religious values, culture, customs, or norms, which forms the economic behavior of Indonesian society. Given the importance of the values of Pancasila, a basic philosophical and sociological of drafting the academic papers of the legislation in a business activity must be based on the values of the locality above. These values are transformed into a legal norm which is becoming the soul of the arrangement of business activity concerned.

Therefore, this research focuses on the adoption of the value of Pancasila in Business Activities. Case studies that are used in this research are from the cooperation and Limited Liability Company and forms of application of the values of Pancasila in Cooperation and Limited Liability Company. The findings of this research are expected to be the basis for development of philosophical and sociological foundation for the development of the law of business activities in Indonesian. Based on the background of the problem, then the problem is formulated, namely: what are the values of Pancasila which can be applied in business activities?

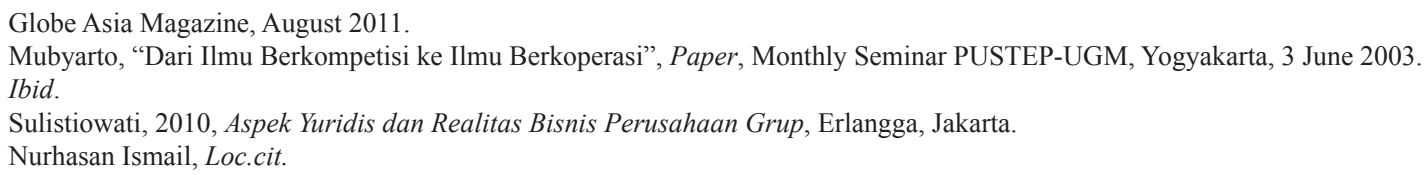




\section{B. Research Methods}

This research uses a socio-legal approach that addresses the relationship values of Pancasila as the nation's philosophy of life and economic law as the legal basis for development of business activities in Indonesia. This research approach based on the realities of the plurality of business activities in Indonesia by combining the values of Pancasila as the philosophy of the nation with the values of economic law that emphasis on the principles of individual, freedom and the quest for profit. ${ }^{10}$

A mix of principles selectively chosen from the modern social values and local wisdom, prismatic law can serve as an instrument for creating the 2 (two) different group of interest. First, the law must be derived from different social values so that in one hand can encourage the progress but on the other hand there is no group to be left. Second, the law encourages strong group to do activities on a competitive basis, but the law should encourage States to give attention to vulnerable groups to prevent higher social and economic inequalities.

This research uses a prismatic law with SocioEconomic Law approach to explore the values of Pancasila in business activity that integrates local values and modern business activities in Indonesia.

The purpose of research is the identification of the values of Pancasila in business activities with case studies of cooperation and limited liability Company in Indonesia. To achieve that goal, researchers will identify the values of Pancasila and modern used as the basis for drafting the economic law in Indonesia. Identification of these values obtained from the analysis of data from various academic texts and research results obtained from the National Law Development Agency, Ministry of Justice and Human Rights. Next, the researchers will conduct FGD to obtain in-depth information on the various parties.

\section{Research Result and Discussion}

Pancasila as the philosophical basis and ideology of the nation of Indonesia, are not formed suddenly and not only created by a person as in the case of other ideologies in the world, but the formation of Pancasila through a long process in Indonesia's history. The founders of the State of Indonesia (the founding fathers) in the process of formulating Pancasila, exploring the values owned by the Indonesian nation, and synthesized within the great thoughts of the world. The values contained in the culture of Indonesian people before building a state. ${ }^{11}$

Historically, Pancasila is intended as philosophiche grondslag, a philosophical basis, for the establishment of the State of Indonesia. The founders of the countries to formulate a basic philosophical was tipped on weltanschauung, views of the life of the nation in the form of fundamental values, the values of divinity, humanity, unity/ nationality, democracy, and social justice are believed to be true, kindness, and its use by the Indonesian nation as source of moral values and norms for the enforcement and management of common life both in the nation and the state. ${ }^{12}$

In the context of national life, Pancasila is "life force" (l'elan vital) and "adhesion" to the unity among the component nations. In the context of statehood, Pancasila became a source of value for the "political philosophy-state" and also "political ethics" in the management of the state. As the consequence, the systems and management of statehood should be based on and refers to Pancasila. In order to keep Pancasila as the living values then the education of Pancasila is a necessary requirement. ${ }^{13}$

The values of Pancasila as the basic philosophy of the Indonesian state in essence is a source of all sources of law in the state of Indonesia. As a source of all sources of law objectively is a

\footnotetext{
Nurhasan Ismail, Loc.cit.

Kaelan, 2014, Pendidikan Pancasila, Paradigma, Yogyakarta, p. 97.

Conclusion of Pancasila Congress I Year 2009 at Yogyakarta, which compile on a book of Proceeding of Pancasila Congress, General Secretariat of Constitutional Court, Jakarta, p. 53.
}

13 Ibid. 
way of life, consciousness, the ideals of law, as well as the character of the Indonesian, which on 18 August 1945 has been compressed and abstracted by the founders of the state into five precepts and set formally as a basis philosophy of the Republic of Indonesia. As what been set out in Ketetapan No. XX/MPRS/1966. ${ }^{14}$

Pancasila is the source of all laws of the country. As a basic philosophy of the state, the principles of Pancasila is a value system, therefore the principles of Pancasila was essentially a unity. Although in each of the precepts contained different values from one another, but all is obviously constitute a systematic unity. ${ }^{15}$

\section{The Values of Pancasila that Can Be} Applied in Business Activities

State economic development of Indonesia becomes one aspect of national life which is important for structured by applying the values of Pancasila. The basis and starting point in the economic development of Indonesia is summed up in Article 33 of the 1945 Constution of Indonesia ("UUD 1945"). The economic basis of Pancasila is summed up in Article 33, which is actually an Economic Democracy, since the economy is structured as a joint venture based on the principle of the family. This Article is important, because it is the basis and starting point in the economic development of Indonesia. The purpose of the national economy is the social welfare and prosperity for the people.

The national economy shall be organized based on economic democracy with the principles of togetherness, efficiency with justice, sustainability, environmental friendliness, independence, and balancing economic progress and the unity of national economy. ${ }^{16}$ Economic development based on economic democracy determines the people to play an active role in development activities. While the Government is obliged to provide direction and guidance to the economic growth and create a healthy circumstance for business growth, and on the other hand, the business world is expected to emerge in response to the direction and guidance as well as participate in creating a healthy circumstance. ${ }^{17}$

The importance of the values of Pancasila, becoming a liability to be relied on in all aspects in the context of Indonesia's economic development. The business activities become an important factor in the economic development of Indonesia. Implementation of the values of Pancasila in business activities excavated and built from the values espoused in Indonesian society, which can be derived from the values of religion, culture, customs, or norms, which forms the economic behavior of Indonesian society. For the implementation of the value of Pancasila in business activities in Indonesia, the academic papers and legislation that regulate and supervise the execution of business activities must make the values of Pancasila as the basic philosophical and sociological in their drafting.

\section{a. Elaboration of the precepts of Panca- sila into the values and principles of law, namely: \\ Man in the life with another human} being needs the guidelines to behave in order to create social order and prevent conflicts of interest that would result to a conflict. Through the code of conduct, human adjusts the behavior and their interest to each other. There are 3 (three) levels of the code of conduct in human life, which are the Social Values, Principles of Law, and the norm of law.

The three levels of the code of conduct is hierarchical. Social value is the highest guidelines and abstract because it comes from the assumptions/beliefs about good and not

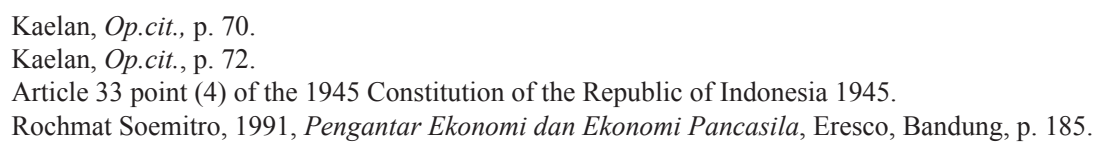


good, appropriate-inappropriate, right and wrong behavior. In any community or tribe or nation both in the history and trajectory of the region must have a notion/belief of good things and bad things. The social value can be categorized into traditionally inclined to collectivity with all elaborated values, Modern are inclined to individualism with all elaborated values, and Prismatic which accommodates traditional values with modern simultaneously in equality and proportionate.

The principle of the law is the code of conduct which constitutes as a bridge between social values with concrete norms. Legal principles span the hierarchy of the social values of traditional, modern, and prismatic linearly. Furthermore, the principle of law becomes a source for the development of concrete norm. In das sollen, the legal principle that span the hierarchy of traditional social values will bear legal norms in line. Likewise, the legal principle that span the hierarchy of modern social values and prismatic will bear legal norms in line.

If it Ontological, Pancasila is understood as a combination of traditional and modernity, then Social Values, Legal Principles and Norms of Law as elaborated, tended to be "Prismatic". Prismatism values, principles and norms implies a blend of: The nature of the profane with the sacred human life, human nature of individual and social, Nationalism by opening up in the international arena, the Organization representative to the people who are represented as the source, and orientation of material welfare along with immaterial of all groups and individuals.

Indonesia has set Pancasila as an ideology, the basic philosophy of the state, and the source of all sources of law. In a multi-position mentioned above, Pancasila with the fifth principle, contain social values that should be identified and translated into principles of law in all spheres of life, or the field of law. Of the principles of this law, concrete legal norms which will be poured in the legislation is shaped both by the legislative and the executive and judicial branches.

This research is part of an effort to one side deductively elaborates principles of Pancasila into social value then elaborated into a principle of law that will be the basis for the development of a special law related to business activities. Furthermore, from the other side, inductively examine the substance of the legislation and practice of conduct of business activities that take place in legal entities in the form of cooperation and limited liability companies. In this section, the descriptions focused on deductive process of Pancasila become social values, legal principles and parameters that can be used as guidelines to identify its descriptions in the legislation.

The deductive elaboration process is conducted through 3 (three) phases which can be explained as follows:

1) Elaboration of Precepts Pancasila into the Social Values;

2) Elaboration of Social Values Into Law Principles; and

3) Determine the Parameter of Each Principles of Law.

b. Elaboration of the precepts of Pancasila into the social values, namely:

Pancasila consists of 5 (five) Precepts but inter-related to each other. The first precept underlying precepts of the second, third, and fourth hierarchical leads to the achievement of the objectives contained in the fifth precepts. Based on the deductive process and selectively to the substance and meaning of each Pancasila, this research resulted in selection of social values as follows:

1) Precept of "Ketuhanan Yang Maha Esa" 
From a number of substances and meaning of the First Precept, it can be summed up 3 (three) social values, namely:

a) The value of the Eternal God the Absolute

Value of the eternity God and man are different. God is absolute immortality that His existence will continue forever, while the value of eternity that can be applied to the life of man is only relative. That is, there is a spirit to maintain social relationships or legal relationship that exists as long as possible.

b) Awareness of Human Relationship With God (Vertical)

Consciousness is an attitude of heart that is expected to manifest into human behavior. One of consciousness must exist in every Indonesian is the relationship between himself and God. Such awareness must accompany any amount of works done by humans, so any action will be placed as part of the worship of God.

c) The embodiment of Vertical Linkages into Human Relationships (Horizontal) If man is able to put his actions as part of a worship to God, then the expectation would be achieved also into the reality of the relationship among humans. That is, the relationship would be based by Godly values.

2) Precept of "Kemanusiaan Yang Adil dan Beradab"

From a number of substance and meaning of the Second Precept, it can be summed up 4 (four) social values, namely:

a) Monodualism of Human Existence

Man was created with the components of the paired namely individual-collective and bodysoul. Couple these components must be acknowledged its existence and should be the foundation in building a state policy.

b) Pluralism aspects of human life Humans have a tendency to live in groups with differences found in each group regarding both the underlying values and behavioral forms that born from the values believed. Differences occurred as a result of each group's response to the physical environment of natural and social environment. The function of the state as an entity built by different groups is to bring together different values and forms of behavior with the bases on the difference so that on one side there are similarities in the level of per se but on the other side to respect differences.

c) Fair in addressing \& Treats Monodualism \& Pluralism

Awareness of monodualism in every human being and pluralism among the groups became the basis for developing a tolerant attitude and respect of each other. Both attitudes should be the basis for the development of social and legal relations among human beings in order to build togetherness and to prevent conflict or dispute. 
3) Third Precept of "Persatuan Indonesia"

From a number of substance and meaning of the Third Precept, it can be summed up 3 (three) social values, namely:

a) Indonesian as a Binder of Plural Human

The diversity of Indonesian society requires a binding entity to unite. The commitment to build a bond of nationality is a momentum to build a binding entity.

b) The State and its equipment and group, as an instruments of national bondage guard

State as an organization of power built by the people of Indonesia were given the authority to establish policies and arrangements that oriented on maintenance of national unity while respecting the diversity that exists. All equipment in good state legislative and the executive and judiciary should be the executor of authority of the state by the orientation to strength the bond of nationality and not weaken; and

c) Indonesian as part of human life that live in nation-state

As part of the nations, the Indonesian people have to open to the presence of the citizens of other nations. Nevertheless, the presence of citizens of other nations does not bring obstacles to prioritizing the interests of the Indonesian people.

4) Precept of "Kerakyatan Yang Dipimpin oleh Hikmah Kebjiksanaan/Perwakilan"
From a number of substance and meaning of the Fourth Precept, it can be summed up 3 (three) social values, namely:

a) People are Centrifugal (Source) $\&$ Centripetal (Orientation)

People become source of sustainability of the country. The voice and interests of the people shall be the basis of the legitimacy of the existence of the state policy and fittings. All policies and state management including executive and judicative performance should be oriented to the demands and interests of the people.

b) The existence of a representative system in arranging and managing the activities/interests together

Legislative branches should really put itself as a fitting voice and interests of the people and put it as a measure of the success of the performance.

c) Deliberation and wise attitude underlying the decision making and solving problem together Deliberation is the process of listening to each other, give each other and take each other that goes voluntarily in order to reach agreement so that the interests of all people and groups are accommodated. Deliberation becomes a media for making decisions and solving the nation's problem.

5) Precept of "Keadilan Sosial Bagi Seluruh Rakyat Indonesia" From a number of substance and meaning of the Fifth Precept, it can be summed up 1 (one) social values, 
namely: Equitable Welfare for All groups and individuals both material and immaterial as the orientation of the precepts before.

Welfare distribution means all people and groups in the regions of the country must acquire and enjoy prosperity in material and immaterial. Significantly, their material welfare of prosperity is the fulfillment of minimum basic needs of all people and groups. Welfare immaterial means the existence of sense of ease and safe in people's lives.

c. Elaboration of social values into law principle, namely:

Based on the social values that are taken as descriptions of each Precepts above, then there are being developed the law principles which are rated as elaboration, namely:

1) The value of the Absolute Eternal God, containing 2 (two) principles of law, namely:

a) The principle of the placement of each activity as a part of worship; and

b) The principle of relative eternity of human relations, and human resources in Indonesia.

With both of these principles, the value of eternity God will underlie the behavior of law any person or legal relationship between individuals so as to create legal behavior is always oriented to the good. Among other things, by placing the legal behavior as part of worship and seek mutual benefit so that the legal relationships that occur can be maintained continuity.

2) Awareness of Human Relationship with God (Vertical), containing legal principles, namely:

a) Principle of recognition of the natural resources and wealth as a blessing and a deposit of God; and

b) Principles of Vertical Accountability i.e. every execution of tasks must be justified in God.

With both of these principles, individuals, and groups are required to put all the good fortune that is held in common as a nation or a group or individual that belongs to an individual or legal entity as a gift and surrogate of God. Thus, as a nation and groups as well as individuals and legal entities will endeavor to use and exploit the wealth of existing as well as possible while maintaining the sustainability. This is because we have to responsible both to fellow human beings and to God.

d. Vertical relations embodiment into human relationship, namely:

a) The principle of mutual respect for the rights and obligations that own by each person;

b) The principle of every action oriented towards everyone prosperity; and

c) The principle of every action should be implemented based on honesty (good faith).

By placing all the wealth of God and its use as a deposit will be responsible to God, every person in the legal acts or legal relationship with another person is required to take advantage of the right/authority existed and to do the obligations with honesty, respecting the rights of others, and for mutual prosperity.

e. Monodulaism of human existence, consist law principles, namely:

1) The principle of balance between the interests of the individual with social interests; and 
2) The principle of guaranteed protection and fulfillment of the needs and interests of every human body and soul.

With both of these principles, any person (natural or legal) that do legal actions or legal relationship with others and always have orientations, beside for the self-interest, also give contribution to the other interest in order to make sure that each person is able to maintain healthy body and soul.

\section{f. Pluralism aspects of human life, it} contains legal principles, namely:

1) The principle of willingness to share interests among different groups; and

2) The principle of recognition of diversity as a basis to build togetherness.

With both of these principles, each person required to build awareness of the differences between themselves or with a group of people or any other group, and the awareness that the existence of himself and the group is only have a meaning because of the presence of another person or group. Therefore, the consequences of such awareness is the willingness to share with people or different groups in order to continue the existence and self-interest or the group-interest. Unwillingness to share with another person or group will have an impact on weakening of the existence and self or group interest.

g. Fair in dealing \& treating monodualism \& pluralism, containing legal principles, namely:

1) The principle of prohibition of exploitation of natural resources which would cause damage;

2) The principle of the prohibition of acts causing harm to others; and

3) The principle of balance between the right to itself with social obligations to the community, nation, and state.

With the principles of this law, any person (natural or legal) not to take legal actions or legal relationships which lead to the utilization of natural resource exploitation and extortion against fellow human beings because it will lead to an imbalance between the rights and obligations themselves. A further consequence of damage to natural resources would be catastrophic for human life itself and socio-economic inequality between groups of men.

h. Indonesian as a binder of plural human, containing legal principles, namely:

1) Principle of recognition and respect for diversity to strengthen the bonds of nationhood and statehood; and

2) Prohibition of acts/activities that weaken national ties.

With the principles of this law, everyone must develop an attitude or awareness of the differences between the groups that exist in the hope that awareness will encourage behavior to give mutual respect for difference and instead put the difference as the driving force to complement each other in building togetherness.

i. State and tool equipment as well as groups like other instruments of national ties guards, containing legal principles, namely:

1) The principle of diversity of the Association of Law in the unity of the nation and the State; and

2) Law/State policy built as a unifying instrument while respecting the diversity of existing laws in society.

With the principles of this law, the state as an organization given responsibility 
for building awareness of the diversity and respectful behavior through its policies and the legal establishment. State cannot establish policies and laws that lead to the weakening the bond of unity or nationality.

\section{j. Indonesian Nation as part of human life as a nation-state, containing legal principles, namely:}

1) The principle of granting access to other nations to carry out activities in Indonesia as a way to ensure the general welfare of the nation of Indonesia; and

2) The principle of granting certain rights over certain resources for other nations with certain restrictions in the interest of the nation Indonesia.

The principles of this law provides the opportunity or access to the citizens of other nations to come and do activities in Indonesia as well as gaining the access utilizing existing resources in Indonesia, but the utilization of resources by the citizens of other nations must provide benefits to the citizens of the nation of Indonesia and granted with certain restrictions,

\section{k. People become centrifugal (source)}

\& centripetal (orientation), contains the principle of law, namely the state policy and any entity sourced and oriented on the will and interests of citizens

Principle of law requires that the state policy as well as the establishment and implementation of the law should be sourced from the legal culture and way of life that thrive in Indonesian society and must be oriented to the interests of the people. This means demanding a democratic process and the necessity of social control both in the formulation and implementation.
1. The existence of representative system and managing the activities/ citizens interests, contain legal principles, namely:

1) The similarity between the will and interests between the people/citizens of the State and any entity;

2) The principle of involvement of people/citizens in political activities, planning and implementation of State policies and other legal entity; and

3) The principle of the conduct of State/entity shall be accountable for implementation of the duty to the citizens.

With these legal principles, equipment in good state legislative and the executive and judiciary in implementing its authority should be oriented towards achieving the people's interests as the interests of the state must be based on the interests of the people. Equipment in developing countries do not develop state's interests if it is against the interests of the people. Equipment in the state must responsible the implementation of the authority that belongs not to the state but to the people because the people who make up the state and the sovereign.

m. Deliberation and wise attitude underlies decision making and solving problem together, contain legal principles, namely:

1) The principle of promoting unity in action;

2) The principle of implementing this mandate in a responsible manner to the grantor of the trust;

3) The principle of cooperativeness in carrying out any social activities; and

4) The principle of familial/ togetherness in carrying out economic activities. 
With the principles of this law, any person (natural or legal entity) or groups are required to develop attitudes and behaviors based on the spirit of brotherhood and togetherness. Social activities by citizens carried out in the spirit of mutual cooperation and oriented to the common interest. Economic activity by businesses conducted in a spirit of joint ownership, optimization of production, and the willingness to share on the economic value of the results obtained. Political activity by politicians conducted in a spirit of togetherness so that the position or positions obtained simply placed as a trust that must be oriented in the interest of the mandate.

n. Equitable welfare for all groups and individuals both material and immaterial, containing legal principles, namely:

1) The principle of equality of access to resources to create equalization;

2) The principle of giving incentives and services for people who excel;

3) The principle difference in treatment that is positive for the achievement of similarity socioeconomic-political;

4) The principle of liability utilize resources in a productive or wealth; and

5) The principle of utilization of certain ownership rights have social and ecological impacts.

The principles of this law requires that all activities undertaken on the basis of the principle of the precepts that others should be oriented towards the creation of equitable welfare of material and immaterial. Welfare distribution can only be manifested if: (a) everyone is given the same access to obtain and utilize existing resources both natural resources and sources of knowledge, capital, and technology; (b) the parties that has the achievement for mutual interest in the utilization of existing resources should be given incentives, but rather those who would damage and displaced the use of resources as well as existing resources should be given disincentives; (c) the parties are in the condition of a weak socio-economicpolitical should be given special treatment to get empowerment and facilities in order to have the ability to control and utilize existing resources well and productively.

\section{Determination of Parameter of Each Principle of Law}

Parameters become methodological instruments in order to identify the elaboration of their respective legal principles into the substance of the legislation and behaviors related to the implementation of business activity in cooperation and limited liability company which is the object of this research. These parameters are presented in the following table:

Table 1.

Indicators of each Principle of Law in Business Activities that Implement the Value of Pancasila

\begin{tabular}{lll}
\hline No. & Description of Principle of Law & Indicators of Each Principle \\
\hline 1 & $\begin{array}{l}\text { The principle of the placement of each } \\
\text { activity as a part of worship }\end{array}$ & $\begin{array}{l}\text { The conditions/behaviors that support every activity as } \\
\text { a part of worship }\end{array}$ \\
\hline 2 & $\begin{array}{l}\text { The principle of relative eternity of } \\
\text { human relations, and human resources } \\
\text { in Indonesia }\end{array}$ & $\begin{array}{l}\text { There is an effort to build working relationships and } \\
\text { sustainable business }\end{array}$ \\
\hline 3 & $\begin{array}{l}\text { The principle of recognition of natural } \\
\text { resources and wealth as a blessing and a } \\
\text { give from God; and }\end{array}$ & $\begin{array}{l}\text { The rule that states that all of the resources and the } \\
\text { work and effort as a gift from God }\end{array}$ \\
\hline
\end{tabular}




\begin{tabular}{|c|c|c|}
\hline No. & Description of Principle of Law & Indicators of Each Principle \\
\hline 4 & $\begin{array}{l}\text { Vertical Accountability principle which } \\
\text { places every execution of tasks can be } \\
\text { responsible to God }\end{array}$ & $\begin{array}{l}\text { There is an obligation to give responsible for any } \\
\text { performance/effort to the God }\end{array}$ \\
\hline 5 & $\begin{array}{l}\text { The principle of mutual respect for the } \\
\text { rights and obligations that own by each } \\
\text { person }\end{array}$ & $\begin{array}{l}\text { Existence of provisions to protect the rights and } \\
\text { obligations of each party in the employment/business } \\
\text { relationship }\end{array}$ \\
\hline 6 & $\begin{array}{l}\text { The principle of every action is oriented } \\
\text { towards everyone prosperity }\end{array}$ & $\begin{array}{l}\text { - Respect the work and achievements of someone in } \\
\text { the form of a decent wage and not harming each other } \\
\text { - There is an openness in the working relationship/ } \\
\text { business that is the report: (1) its own business } \\
\text { activities; (2) Balance of income }\end{array}$ \\
\hline 7 & $\begin{array}{l}\text { The principle of balance between the } \\
\text { interests of the individual with social } \\
\text { interests }\end{array}$ & $\begin{array}{l}\text { a. The progress of business activities must be balanced } \\
\text { with the welfare of workers/members } \\
\text { b. Progress of business is rated by the development } \\
\text { level of production (benefit) and profit }\end{array}$ \\
\hline 8 & $\begin{array}{l}\text { The principle of collateral protection } \\
\text { and fulfilling the needs and interests of } \\
\text { every human body and soul }\end{array}$ & $\begin{array}{l}\text { The progress of business activities must be balanced } \\
\text { with the welfare of workers/members } \\
\text { Welfare is measured from: (1) salary or dividends or } \\
\text { SHU; (2) a guarantee of health care or social security }\end{array}$ \\
\hline 9 & $\begin{array}{l}\text { The principle of willingness to share } \\
\text { interests among different groups. }\end{array}$ & $\begin{array}{l}\text { An express division of authority for all organs of the } \\
\text { legal entity (business) }\end{array}$ \\
\hline 10 & $\begin{array}{l}\text { The principle of recognition of diversity } \\
\text { as a basis to build togetherness }\end{array}$ & $\begin{array}{l}\text { a. Giving equal opportunity to everyone to work } \\
\text { and be the owner or a member of the enterprise } \\
\text { regardless of distinction SARA } \\
\text { b. Appreciating the differences of opinion in decision } \\
\text { making related to business activities }\end{array}$ \\
\hline 11 & $\begin{array}{l}\text { The principle of prohibition of } \\
\text { exploitation of natural resources which } \\
\text { would cause damages }\end{array}$ & $\begin{array}{l}\text { a. The existence of licensing as the direction, control } \\
\text { and supervision of the implementation of business } \\
\text { activities in order to prevent negative impact on the } \\
\text { environment } \\
\text { b. Obligation for the businessman to maintain the } \\
\text { sustainability of the natural environment }\end{array}$ \\
\hline
\end{tabular}

12 The principle of the prohibition to The recognition which balanced (proportional) the actions that causing harm to others position and role of each shareholder or member in the enterprise

13 The principle of balance between the a. The obligation to prioritize the larger interests than right to itself with social obligations to the community, nation, and state the interests of his own

b. The independence of every organ in implementing authority in order to create the purpose of entities

14 The principle of prohibition on There is a clear and feasible provision of working time exploitation by one against the other; and amount of salary, also providing overtime salary and for exceeding the working time

15 The principle of respect for the rights and interests of parties or other groups

a. the existence of transparency on any process in publications and responsible for the negative effects arising from the activities carried out (corporate liability)

b. The requirement for businesses to provide corporate social responsibility for the benefit of society and the natural environment 


\begin{tabular}{lll}
\hline No. & Description of Principle of Law & Indicators of Each Principle \\
\hline 16 & $\begin{array}{l}\text { The principle of recognition and respect } \\
\text { for diversity to strengthen the bonds of } \\
\text { nationhood and statehood }\end{array}$ & $\begin{array}{l}\text { Giving chance proportionally among the locals/regions } \\
\text { around the company with people who come from } \\
\text { outside to become labor/capital owners/members of } \\
\text { the enterprise }\end{array}$ \\
\hline $17 \quad \begin{array}{l}\text { Prohibition of actions/activities that } \\
\text { weaken national ties }\end{array}$ & $\begin{array}{l}\text { a. The existence of balance between the purpose of } \\
\text { business activities by business entities with the goal } \\
\text { of nation } \\
\text { b. Every plan in developing the business activity whose } \\
\text { implementation is given to the business entities } \\
\text { directed on fulfilling the interests of citizens }\end{array}$ \\
\hline
\end{tabular}

18 Diversity of Law Principles in the unity National law must provide access to the legal validity of the Association of State and Nation of the local community customary law

19 State law built as a unifying instrument Giving the opportunity to conduct business activities while respecting the diversity of existing with the nature of monopolies to businesses that are laws in society

20 The principle of giving the access to Legal certainty for foreign enterprises to conduct other nations to carry out activities in business in Indonesia with the obligation to build Indonesia as a way to ensure the general partnerships with Indonesia business entities welfare of the Indonesian; and

21 The principle of giving certain rights The restrictions on business activity that may be given over certain resources to other nations with certain restrictions for the sake of Indonesian interest

$22 \quad$ State policy and any other entity based and oriented on the will and interests of the citizens

\section{to foreign entities}

In decision making related to the implementation of business activities should be involved/be heard the views of stakeholders including workers
23 The similarity between the will and interests of the people/citizens of the State and any other entity;

24 The principle of involvement of people/ citizens in political activities, planning and implementating the State policies and other legal unity

25 The principle that the State/entity shall responsible for the execution of duties to the citizens

26 The principle of promoting unity in a. There is synergy and coordination between organs of action;

Provisions that encourage the similarity of interest and purpose of all components in the company in running its business

Decision-making about the planned business activities carried out by involving all the owners and employees

Leader companies shall openly state the achievement of business activity enterprises in the implementation of the authority to create business purpose

b. Each entity was given the freedom to conduct business for profit but should be burdened with certain obligations such as CSR or build some partnerships

27 The principle of carrying out the The existence of punishment as a form of liability for mandate responsibly from the party who wrongful acts in the implementation of businessman give the trust authority

28 The principle of mutual cooperation in Settlement of disputes or problems related to the actions implementing any social activities on business activities should be directed at the use of deliberations to achieve a win-win solution

29 Principle of family/togetherness in The decision in the operation of business activities carrying out economic activities should be pursued based on the views and interests of all stakeholders 


\begin{tabular}{|c|c|c|}
\hline No. & Description of Principle of Law & Indicators of Each Principle \\
\hline 30 & $\begin{array}{l}\text { The principle of equality of access to } \\
\text { gain resources to create equity; }\end{array}$ & $\begin{array}{l}\text { a. There is the same chance to carry out business } \\
\text { activities for each entity } \\
\text { b. No business activities that are monopolized by one } \\
\text { entity/group }\end{array}$ \\
\hline 31 & $\begin{array}{l}\text { The principle of incentives and services } \\
\text { for people who have achievement }\end{array}$ & $\begin{array}{l}\text { The existence of provision of reward and punishment } \\
\text { Business entities are encouraged to provide proper } \\
\text { salary to workers and provide CSR for the surrounding } \\
\text { communities }\end{array}$ \\
\hline 32 & $\begin{array}{l}\text { The principle on differenciate the } \\
\text { treatment in positive ways for the } \\
\text { achievement of equality in socio- } \\
\text { economic-political }\end{array}$ & $\begin{array}{l}\text { Give special treatments (different) to entities that have } \\
\text { a lower capital/small medium micro businesses }\end{array}$ \\
\hline 33 & $\begin{array}{l}\text { The principle to grant the benefit from } \\
\text { the resources or wealth productively }\end{array}$ & $\begin{array}{l}\text { Each entity is encouraged to conduct its operation } \\
\text { productively (producing maximal) }\end{array}$ \\
\hline 34 & $\begin{array}{l}\text { The prinnciple of utilization of certain } \\
\text { ownership rights has social and } \\
\text { ecological impacts }\end{array}$ & $\begin{array}{l}\text { a. Business entities are encouraged to maintain the } \\
\text { sustainability of its resources in order to produce in } \\
\text { a sustainable manner } \\
\text { b. The existence of punishment in the case of losses } \\
\text { that the nature are strict liability/vicarious liability } \\
\text { c. The existence of provisions regarding certain licenses } \\
\text { (such as AMDAL, etc.) that must be fulfilled and } \\
\text { a clear and measurable company's plan in order to } \\
\text { minimize the losses }\end{array}$ \\
\hline
\end{tabular}

Source: compiled by Authors.

\section{Conclusion}

Based on the results of this research and discussion that has been stated, it can be concluded that Pancasila has the nature of abstract, general, and universal, but these natures need to be implemented, embodied and created in the execution and implementation of the State through the norms of law or legislations. The values of Pancasila based on this research, showed very relevant and can be applied in business activities, most of which have been accommodated in legislation governing business activities in Indonesia, but there are also some content values that still not accommodated.

\section{BIBLIOGRAPHY}

\section{A. Books}

Antunes, 1994, Liability of Corporate Groups, Black, Henry Campbell, 1990, Black's Law Dictionary With Pronounciations, Sixth Edition, West Publishing Co., St, Paul Minnesota.

Garner, 1990, Black's Law Dictionary $6^{\text {th }}$ ed., West Publishing.

Kaelan, 2014, Pendidikan Pancasila, Paradigma,
Komite Nasional Kebijakan Governance, 2006, Pedoman Umum Good Corporate Governance Indonesia, KNKG, Jakarta.

Muhammad, Abdulkadir, 2006, Hukum Perusahaan Indonesia, Citra Aditya Bakti, Bandung.

Prasetya, Rudhi, 1996, Kedudukan Mandiri Perseroan Terbatas, Citra Aditya Bakti, Bandung.

Soemitro, Rochmat, 1991, Pengantar Ekonomi dan Yogyakarta. 
Ekonomi Pancasila, Eresco, Bandung.

Sulistiowati, 2010, Aspek Yuridis dan Realitas Bisnis Perusahaan Grup, Erlangga, Jakarta.

Sulistiowati, 2014, Tanggung Jawab Hukum pada Perusahaan Grup di Indonesia, Erlangga, Jakarta.

Widjaja, Gunawan, Ahmad, Yani, 2000, Hukum Arbitrase, Raja Grafindo Persada, Jakarta.

\section{B. Journal Articles}

David, M Trubek, "Max Weber on Law and the Rise of Capitalism", Faculty Scholarship Series, Paper 4001, 1972.

Gold, David A., et al., "Recent Developments in Marxist Theories of the Capitalist State", Monthly Review, Part I , Vol. 27, No. 5, October 1975.

\section{Research/Thesis}

Sulastriyono, 2011, Hukum Sumber Daya Air: Studi Pengelolaan-Pengelolaan Sumber Daya Air Berbasis Nilai-rationNilai Kearifan Lokal di Hulu Sungai Gadjahwong Yogyakarta, Dissertation, Faculty Law Universitas Gadjah Mada, Yogyakarta.

\section{Papers/Speech}

Ismail, Nurhasan, "Hukum Prismatik: Kebutuhan Masyarakat Majemuk Sebuah Pemikiran Awal", Speech, Professor Inauguration at Faculty of Law Universitas Gadjah Mada, Yogyakarta, 2011.

Mubyarto, "Dari Ilmu Berkompetisi ke Ilmu Berkoperasi”, Monthly Seminar PUSTEPUGM, Yogyakarta, 3 June 2003.

Prasetya, Rudhy, "Diskusi Publik Mengenai Pembaruan Hukum Dagang", Paper, Public Discussion on Academic Paper of Commercial Law Bill, BPHN, Jakarta, 31 October 2013.

\section{E. Legislations}

The 1945 Constitution of the Republic of Indonesia. Law Number 17 of 2012 regarding Cooperative (State Gazette of the Republic of Indonesia Year 2012 Number 212, Supplement to State Gazette of the Republic of Indonesia Number 5355).

Law Number 32 of 2009 regarding Environmental Protection and Management (State Gazette of the Republic of Indonesia Year 2009 Number 140, Supplement to State Gazette of the Republic of Indonesia Number 5059).

Law Number 25 of 2007 regarding Investment (State Gazette of the Republic of Indonesia Year 2007 Number 67, Supplement to State Gazette of the Republic of Indonesia Number 4724).

Law Number 40 of 2007 regarding Limited Liability Companies (State Gazette of the Republic of Indonesia Year 2007 Number 106, Supplement to State Gazette of the Republic of Indonesia Number 4756).

Law Number 25 of 1992 regarding Cooperatives (State Gazette of the Republic of Indonesia Year 1992 Number 116, Supplement to State Gazette of the Republic of Indonesia Number 3502).

Law Number 5 of 1999 regarding the Prohibition of Monopolistic Practices and Unfair Business (State Gazette of the Republic of Indonesia Year 1999 Number 33, Supplement to State Gazette of the Republic of Indonesia Number 3817).

Government Regulation Number 43 of 2012 regarding Corporate Social Responsibility (State Gazette of the Republic of Indonesia Year 2012 Number 89, Supplement to State Gazette of the Republic of Indonesia Number 5305). 